\title{
Tagging single-nucleotide polymorphisms in candidate oncogenes and susceptibility to ovarian cancer
}

\author{
L Quaye', H Song', SJ Ramus', A Gentry-Maharaj', E Høgdall ${ }^{3}$ RA DiCioccio ${ }^{4}$, V McGuire ${ }^{5}$, AH Wu ${ }^{6}$, \\ DJ Van Den Berg', MC Pike ${ }^{6}$, E Wozniak', JA Doherty ${ }^{7}$, MA Rossing ${ }^{7}$, RB Ness', KB Moysich ${ }^{4}$, C Høgdall, \\ J Blaakaer ${ }^{10}$, The Ovarian Cancer Association Consortium, DF Easton' ', BAJ Ponder', IJ Jacobs', U Menon', \\ AS Whittemore ${ }^{6}$, S Krüger-Kjaer ${ }^{3,9}$, CL Pearce ${ }^{6}$, PDP Pharoah ${ }^{2}$ and SA Gayther*,1
}

'Gynaecological Oncology Department, UCL EGA Institute for Women's Health, University College London, London, UK; ${ }^{2}$ Strangeways Research Laboratory, CR-UK Department of Oncology, University of Cambridge, Cambridge, UK; ${ }^{3}$ Department of Virus, Hormones and Cancer, Institute of Cancer Epidemiology, Danish Cancer Society, Copenhagen, Denmark; ${ }^{4}$ Department of Cancer Genetics, Roswell Park Cancer Institute, Buffalo, NY, USA; ${ }^{5}$ Department of Health Research and Policy, Stanford University School of Medicine, Stanford, CA, USA; ${ }^{6}$ Department of Preventive Medicine, University of Southern California, Keck School of Medicine, Los Angeles, CA, USA; ${ }^{j}$ J Program in Epidemiology, Division of Public Health Sciences, Fred Hutchinson Cancer Research Center, Seattle, WA, USA; ${ }^{8}$ Department of Epidemiology and University of Pittsburgh Cancer Institute, Pittsburgh, PA, USA; ${ }^{9}$ Gynaecology Clinic, The Juliane Marie Centre, Rigshospitalet, University of Copenhagen, Denmark, CR-UK; ${ }^{10}$ Department of Gynaecology and Obstetrics, Aarhus University Hospital, Skejby, Aarhus, Denmark; "'Department of Oncology, Strangeways Research Laboratory, Genetic Epidemiology Unit, University of Cambridge, Cambridge, UK

Low-moderate risk alleles that are relatively common in the population may explain a significant proportion of the excess familial risk of ovarian cancer (OC) not attributed to highly penetrant genes. In this study, we evaluated the risks of OC associated with common germline variants in five oncogenes (BRAF, ERBB2, KRAS, NMI and PIK3CA) known to be involved in OC development. Thirty-four tagging SNPs in these genes were genotyped in $~ 1800$ invasive OC cases and 3000 controls from population-based studies in Denmark, the United Kingdom and the United States. We found no evidence of disease association for SNPs in BRAF, KRAS, ERBB2 and PIK3CA when OC was considered as a single disease phenotype; but after stratification by histological subtype, we found borderline evidence of association for SNPs in KRAS and BRAF with mucinous OC and in ERBB2 and PIK3CA with endometrioid OC. For NMI, we identified a SNP ( $\mathrm{rs}$ | I 683487) that was associated with a decreased risk of OC (unadjusted $P_{\text {dominant }}=0.004$ ). We then genotyped rs I 1683487 in another 1097 cases and 1792 controls from an additional three case-control studies from the United States. The combined odds ratio was 0.89 (95\% confidence interval $(\mathrm{Cl}): 0.80-0.99)$ and remained statistically significant $\left(P_{\text {dominant }}=0.032\right)$. We also identified two haplotypes in ERBB2 associated with an increased $O C$ risk $\left(P_{\text {global }}=0.034\right)$ and a haplotype in BRAF that had a protective effect $\left(P_{\text {global }}=0.005\right)$. In conclusion, these data provide borderline evidence of association for common allelic variation in the NMI with risk of epithelial OC.

British Journal of Cancer (2009) 1 00,993-100 I. doi:I0.1038/sj.bjc.6604947 www.bjcancer.com

Published online 24 February 2009

(C) 2009 Cancer Research UK

Keywords: risk of ovarian cancer; polymorphism; oncogene; association studies

Globally, ovarian cancer (OC) is responsible for approximately 125000 deaths each year (Parkin et al, 2005). The risk to firstdegree relatives of an OC case is increased above population rates (Stratton et al, 1997) and twin studies suggest that genes are more important than shared environment (Lichtenstein et al, 2000); however, most cases occur without any obvious evidence of inherited susceptibility (i.e., they appear to be sporadic). The two highly penetrant susceptibility genes $B R C A 1$ and $B R C A 2$ are responsible for approximately half of all families containing two or

*Correspondence: Dr SA Gayther, Gynaecological Oncology Unit, University College London, UCL EGA Institute for Women's Health, Paul O'Gorman Building, Chenies Mews, London WCIE 6HX, UK; E-mail: s.gayther@ucl.ac.uk

Received 13 October 2008; revised 19 January 2009; accepted 26 January 2009; published online 24 February 2009 more ovarian cancer cases (Ford et al, 1998; Gayther et al, 1999; Ramus et al, 2007), but these genes account for less than $40 \%$ of the familial excess risk of OC (Antoniou and Easton, 2006). The remaining familial risks are thought to be due to combinations of multiple alleles that confer moderate- or low-penetrance susceptibility (Pharoah et al, 2002).

The most widely used approach to identify moderate/low-risk susceptibility alleles for cancer has been to study candidate genes in biologically relevant pathways. Proto-oncogenes are essential for normal cell function, particularly in the regulation of cell division, proliferation, survival, motility and apoptosis. Activating mutations or amplification of these genes generally elevates growth factor production and stimulates cell mitosis leading to neoplastic transformation (Rhim, 1988; Hogdall et al, 2003a). To date, few studies have reported on the OC risks associated with germline genetic variation in proto-oncogenes. A variant of borderline significance has been reported in the putative oncogene AURKA 
(earlier known as STK15) (Dicioccio et al, 2004). However, this was not confirmed in a larger consortium study (Ramus et al, 2008). Most of the oncogenes known to be altered in OC development have not yet been studied.

Of the oncogenes known to be involved in OC, KRAS is the most frequently mutated (Forbes et al, 2006). KRAS functions in the receptor tyrosine kinase pathway (Gemignani et al, 2003) and several other genes that function in this pathway are mutated in multiple tumour types (Cuatrecasas et al, 1997). Activating mutations of KRAS appear to be an early event in OC development, but predominantly tumours of the mucinous histological subtype (Gemignani et al, 2003). Mutations in codons 12 and 13 have been detected in approximately $50 \%$ of mucinous OCs (Gemignani et al, 2003). $B R A F$, in the mitogen-activated protein kinase pathway, is a downstream effector of KRAS and is critical in the transduction of cell growth signals (Cuatrecasas et al, 1998). Overexpression of $B R A F$ has been found in a variety of cancers, and mutations have been reported in $12 \%$ of OCs (Gemignani et al, 2003; Russell and McCluggage, 2004; Sieben et al, 2004).

PIK3CA is the catalytic subunit of the lipid kinase phosphatidylinositol 3-kinase (PIK), which is involved in the regulation of cell proliferation, adhesion transformation, survival, apoptosis and motility (Volinia et al, 1994; Fruman et al, 1998; Cantley, 2002). The helical and kinase domains of PIK3CA are hotspots for mutations, which have been found in multiple tumour types including ovary, breast, lung, brain, colon and stomach (Muller et al, 2007). PIK3CA mutations have been shown to correlate with increased gene expression in several OC cells lines. Detectable amplification of the gene has also been shown in $58 \%$ of ovarian tumours using fluorescence in situ hybridisation (Shayesteh et al, 1999).

The human epidermal growth factor receptor-2 gene, ERBB2 $(H E R-2 / N e u)$, is a transmembrane protein that acts as a growth factor receptor and is involved in cell proliferation and cell differentiation (Wu et al, 2004). Breast, prostate, lung, gastrointestinal, kidney, liver and bladder cancers have all shown an elevated expression of ERBB2 (Wu et al, 2004). For OC, $20-30 \%$ of primary stage III/IV tumours show ERBB2 overexpression (Hellstrom et al, 2001). Protein expression using antibody staining on a subset of ovarian tumours from the MALOVA study showed that $39 \%$ of the carcinomas overexpressed ERBB2 (Hogdall et al, 2003b).

The MYC family of proto-oncogenes, including $N M Y C$ and $M Y C$, and their interacting partners, are transcription factors that have a well-documented role in tumourigenesis. MYC overexpression caused by gene amplification induces uncontrolled hyper-proliferation and occurs in $\sim 35 \%$ of epithelial OCs. Another gene, the NMYC and STAT interactor (NMI), which interacts with $N M Y C, M Y C, M A X, F O S$, other transcription factors (Zhu et al, 1999) and BRCA1 (Li et al, 2002), is overexpressed in human leukaemias and other cancers (Bao and Zervos, 1996).

The aim of this study was to evaluate the risks of OC associated with common genetic variation in five of the candidate oncogenes described above - BRAF, ERBB, KRAS, NMI and PIK3CA - using a SNP-tagging approach. To do this, we genotyped 34 common tagging SNPs (tSNPs) in 1816 invasive epithelial OC cases and 3000 unaffected controls from five different case-control studies from the United States, United Kingdom and Denmark as part of a multicentre collaboration. We then evaluated one positive finding in a further 1097 cases and 1712 controls from three other US studies.

\section{MATERIALS AND METHODS}

\section{Study individuals}

In the first stage of this study, we genotyped OC cases and controls from five different populations. These were (1) The Danish MALOVA study (446 cases and 1221 controls); (2) The UK
SEARCH study (730 cases and 855 controls); (3) The Genetic Epidemiology of Ovarian Cancer Study (GEOCS; previously FROC) from Stanford, CA, USA (327 cases and 429 controls); (4) The USC (A) study from Los Angeles, CA, USA (197 cases and 224 controls); and (5) the UKOPS study from the United Kingdom (116 cases and 271 controls). In stage 2 , a putative positive association was followed up in three other case-control studies: (1) The USC (B) study, CA, USA (237 cases and 360 controls); (2) The DOVE study, Seattle, WA, USA (584 cases and 716 controls); and (3) The HOPE study, Pittsburgh, USA (276 cases and 636 controls). USC (A) and (B) are subsets of the same USC population. The USC (A) samples were collected between 2000 and 2004 and USC (B) samples were collected from 1993 to 1999. All study individuals were nonHispanic Whites. Details for several of these studies have been published before (Dicioccio et al, 2004; Pearce et al, 2005; Song et al, 2006, 2007; Gayther et al, 2007; Rossing et al, 2007) and are summarised in Table 1. Local ethics committee approval was given for the collections and genotyping in all individuals.

\section{Candidate gene and tSNP selection}

We chose to analyse candidate oncogenes for which there is evidence that the genes were amplified or mutated in OCs. The genes we chose to examine initially were BCL2, BRAF, MYC, CTNNB1, EGFR, ERBB2, FGF3, HRAS, KIT, MDM2, NMI and PIK3CA. Some of these genes were excluded if no HapMap genotyping data were available, if the gene was poorly tagged or if there were $<3$ tSNPs or $>15$ tSNPs in the genes. We used data from the CEPH population, from The International HapMap Project Data Rel 20/phase II Jan06 (www.hapmap.org), Haploview version 3.32 (Barrett et al, 2005) and Tagger (de Bakker et al, 2005) to select tSNPs that capture common genetic variation in each candidate gene, and putative regulatory regions up and downstream of the gene (within $5 \mathrm{~kb}$ ), with a minimum squared correlation of $0.8\left(r^{2} \geqslant 0.8\right)$. The multi-marker (aggressive) tagging option of Tagger was used to select tSNPs. If a selected tSNP failed assay design or genotyping, an alternative tagging SNP was chosen.

\section{Genotyping SNPs}

A combination of iPLEX (Sequenom Inc., Hamburg, Germany) and TaqMan ABI 7900HT Sequence Detection System (Applied Biosystems, Warrington, UK) was used to genotype the samples as described earlier (Zhao et al, 2006). The MALOVA and SEARCH samples were genotyped by a combination of TaqMan and iPLEX; UKOPS, USC and GEOCS were genotyped with TaqMan only. Genotyping with iPLEX was performed at the Sequenom laboratory in Hamburg, Germany. TaqMan genotyping of stage 1 samples was performed at the Gynaecological Cancer Research Laboratories, University College London, and Strangeways Research Laboratory, University of Cambridge (both UK). For stage 2, samples were genotyped by TaqMan at the Keck School of Medicine, University of Southern California, USA. Genotyping was repeated for studies/plates when call rates were below $90 \%$, if there were discordant duplicate samples or if negative controls tested positive (Song et al, 2006, 2007; Gayther et al, 2007).

\section{Statistical methods}

Deviation from Hardy-Weinberg equilibrium (HWE) was assessed in controls within study populations using the standard $\chi^{2}$ test. Unconditional logistic regression was used to assess the relationship between each tSNP and risk of OC for each study and pooled across studies (stratified by study), with the primary test of association being a test for trend $\left(P_{\text {trend }}\right)$. The per-allele odds ratio and odds ratios for the heterozygote and rare homozygote relative to the common homozygote were estimated by stratified logistic regression. The programme TagSNPs (Stram et al, 2003) was used 
Table I Ovarian cancer case-control populations included in this study

\begin{tabular}{|c|c|c|c|c|c|c|c|c|}
\hline \multirow[b]{2}{*}{ Population* } & \multicolumn{4}{|c|}{ Controls } & \multicolumn{4}{|c|}{ Cases } \\
\hline & Total & Age & $\begin{array}{l}\text { Participation } \\
\text { rate (\%) }\end{array}$ & Ascertainment & Total & Age & $\begin{array}{l}\text { Participation } \\
\text { rate }(\%)\end{array}$ & Ascertainment \\
\hline $\begin{array}{l}\text { MALOVA } \\
\text { (Denmark) }\end{array}$ & $|22|$ & $35-79$ & 67 & $\begin{array}{l}\text { Random selection of females from } \\
\text { the computerised Central } \\
\text { Population Register. }\end{array}$ & 446 & $35-79$ & 79 & $\begin{array}{l}\text { Incident cases diagnosed between } \\
1994 \text { and } 1999 \text { from municipalities } \\
\text { of Copenhagen and Frederiksberg } \\
\text { and surrounding counties. }\end{array}$ \\
\hline SEARCH (UK) & 855 & $39-77$ & 84 & $\begin{array}{l}\text { Selected from the EPIC-Norfolk } \\
\text { cohort of } 25000 \text { individuals based } \\
\text { in the same geographical regions as } \\
\text { the cases. }\end{array}$ & 730 & $21-74$ & 69 & $\begin{array}{l}\text { Cases from East Anglian West } \\
\text { Midlands and Trent regions of } \\
\text { England. Prevalent cases diagnosed } \\
\text { between 199| and 1998; incident } \\
\text { cases diagnosed } 1998 \text { onwards. }\end{array}$ \\
\hline GEOCS (USA) & 429 & $19-66$ & 75 & $\begin{array}{l}\text { Random-digit dial identification } \\
\text { from study area. Frequency } \\
\text { matched to cases for race/ethnicity } \\
\text { and 5-year age group. }\end{array}$ & 327 & $23-64$ & 75 & $\begin{array}{l}\text { Consecutive cases diagnosed from } \\
1997 \text { to } 2002 \text { in Greater Bay Area } \\
\text { Cancer Registry San Francisco. }\end{array}$ \\
\hline USC (A) (USA) & 224 & $21-78$ & 73 & $\begin{array}{l}\text { Neighbourhood recruited controls, } \\
\text { frequency matched to cases for age } \\
\text { and ethnicity from } 2000 \text { to } 2004 \text {. }\end{array}$ & 197 & $18-84$ & 73 & $\begin{array}{l}\text { Rapid case ascertainment through } \\
\text { Los Angeles Cancer Surveillance } \\
\text { programme from } 2000 \text { to } 2004 \text {. }\end{array}$ \\
\hline UKOPS (UK) & 271 & $50-76$ & 97 & $\begin{array}{l}\text { Apparently healthy } \\
\text { postmenopausal women from the } \\
\text { general population participating in } \\
\text { the United Kingdom Collaborative } \\
\text { Trial of Ovarian Cancer Screening } \\
\text { (UKCTOCS). All women followed } \\
\text { up for cancers through the Office } \\
\text { of National Statistics. }\end{array}$ & 116 & $35-86$ & 86 & $\begin{array}{l}\text { Incident cases from } 10 \\
\text { gynaecological oncology National } \\
\text { Health Service centres throughout } \\
\text { the United Kingdom, from January } \\
2006 \text { onwards. }\end{array}$ \\
\hline Total (stage I) & & 3000 & & & & 1816 & & \\
\hline USC (B) (USA) & 360 & $21-78$ & 73 & $\begin{array}{l}\text { Controls recruited from same } \\
\text { neighbourhoods as cases from } \\
1993 \text { to } 1999, \text { frequency matched } \\
\text { to cases for age and ethnicity. }\end{array}$ & 237 & $18-84$ & 73 & $\begin{array}{l}\text { Cases recruited through the Los } \\
\text { Angeles Cancer Surveillance } \\
\text { programme from } 1993 \text { to } 1999 .\end{array}$ \\
\hline DOVE (USA) & 716 & $35-74$ & 82 & $\begin{array}{l}\text { Random-digit dial identification } \\
\text { from study area. Frequency } \\
\text { matched to cases for race/ethnicity } \\
\text { and 5-year age group. }\end{array}$ & 584 & $35-74$ & 75 & $\begin{array}{l}\text { Cases diagnosed with primary } \\
\text { invasive ovarian cancer between } \\
2002 \text { and } 2005 \text { from a 13-county } \\
\text { area of Western Washington state. }\end{array}$ \\
\hline HOPE (USA) & 636 & $25-80$ & 81 & $\begin{array}{l}\text { Identified in same regions as cases. } \\
\text { Frequency matched for age and } \\
\text { ethnicity. All participants undergo } \\
\text { home interviews. }\end{array}$ & 276 & $25-80$ & 69 & $\begin{array}{l}\text { Variable source including physician } \\
\text { offices cancer registries and } \\
\text { pathology databases from counties } \\
\text { of Western PA Eastern } \mathrm{OH} \text { and } \\
\text { Western NY. }\end{array}$ \\
\hline Total (stage 2) & & 1792 & & & & 1097 & & \\
\hline $\begin{array}{l}\text { TOTAL (stages } \\
\text { I and } 2 \text { ) }\end{array}$ & & 4712 & & & & 2913 & & \\
\hline
\end{tabular}

*All samples are population based. All individuals are non-hispanic Whites.

to model the relevant multi-marker haplotypes resulting from aggressive SNP tagging. Heterogeneity between study strata was tested by comparing logistic regression models with and without a genotype-stratum interaction term using the likelihood ratio test. All the reported $P$-values are two sided. There was no association in controls between age and genotype frequency for any of the SNPs, and adjusting for age did not materially alter the effect estimates and thus age was not included in the models (data not shown). Where there was evidence for association, we compared the fit of log-additive co-dominant, dominant and recessive genetic models using likelihood ratio tests.

We also conducted analyses to determine if haplotype effects were present. Haplotype blocks (regions of strong linkage disequilibrium) were defined using the confidence interval option of Haploview (Gabriel et al, 2002), with minor adjustments to include adjacent SNPs, but maintaining the cumulative frequency of the common haplotypes to $>90 \%$. All genes had one haplotype block, except KRAS, which had two blocks. Haplotype analysis was conducted using the programme TagSNPs (Stram et al, 2003).
TagSNPs implements an expectation-substitution approach to account for the uncertainty caused by the unphased genotype data (Stram et al, 2003). The genotype data for GEOCS, MALOVA, SEARCH, UKOPS and USC (A) samples were used in this analysis. Unconditional logistic regression was used to test the association between each haplotype relative to the most common haplotype (Zaykin et al, 2002; Stram et al, 2003). Haplotypes that occurred with a frequency of $2 \%$ or greater in the combined data were considered 'common', and those with less than $2 \%$ frequency were pooled together as rare haplotypes.

\section{RESULTS}

Forty SNPs were selected to tag the common genetic variation in BRAF, ERBB2, KRAS, NMI and PIK3CA. Six of these (PIK3CA: rs1607237, rs6443624 and rs3729692; KRAS: rs11047912 and rs17388893; BRAF: rs11771946) failed assay design, manufacture or genotype testing and could not be efficiently tagged by any 
other SNP. Therefore, we were able to genotype 34 SNPs in total (Table 2). The tSNPs were selected using HapMap Data Rel 20/ phase II on NCBI B35 assembly, dbSNP b125. For all five genes, we captured 176 of $188(94 \%)$ common SNPs with $r^{2}>0.8$. Tagging efficiencies were the same using the most recent HapMap data release (HapMap Data Rel 21a/phase II on NCBI B35 assembly dbSNPb125), which captured 199 of 212 (94\%) of the common SNPs with $r^{2}>0.8$.

This panel of SNPs was genotyped in five different OC case-control studies from the United Kingdom (SEARCH and UKOPS), United States (GEOCS and USC (A)) and Denmark (MALOVA). Combined, these studies comprise 1816 invasive epithelial OC cases and 3000 unaffected female controls. For most tSNPs, genotype distributions in controls were consistent with HWE in all populations in which genotyping passed quality control criteria. For one SNP (rs2699905), controls from GEOCS, SEARCH and UKOPS deviated significantly from HWE $(P<0.01)$. Seven tSNPs (rs2952155, rs11047917, rs11551174, rs10487888, rs2865084, rs1733832 and rs289831) could not be genotyped for GEOCS, UKOPS and USC (A) because Taqman assays for these tSNPs failed assay manufacture. This is reflected in the variable numbers of cases and/or controls that were successfully genotyped for each tSNP, listed in Table 3.

\section{Association between genotype frequencies and OC risk}

We found no evidence of association between tSNPs or multimarker haplotypes in BRAF, ERBB2, KRAS and PIK3CA and susceptibility to invasive epithelial OC (Table 3 and Supplementary Table 1). A SNP in NMI (rs11683487) showed evidence of association with reduced risk of OC (heterozygous odds ratio (OR) 0.80 (95\% confidence interval (CI) 0.69-0.93); homozygous OR 0.87 (95\% CI $0.71-1.02) ; P_{\text {trend }}=0.038$ ) (Table 3). The bestfitting genetic model for this SNP was a dominant model $(P=0.004)$ (rare allele carriers $v s$ common allele homozygotes OR $0.81(95 \%$ CI $0.71-0.94))$. There was no statistically significant heterogeneity across studies for any SNP.

The association with rs11683487 was investigated further by performing a second stage of genotyping in three additional populations from the United States (USC (B); DOVE and HOPE) (Table 1). Together, these three studies comprised an additional 1097 cases and 1712 controls. There was no association between rs 11683487 and the risk of OC in the samples used for validation on their own $\left(P_{\text {dominant }}=0.92 ; \quad \mathrm{OR}=1.01 \quad(0.85-1.20)\right)$. After combining the data from both stages, the association with rs11683487 was weaker, but still statistically significant $\left(P_{\text {dominant }}=0.032 ; \mathrm{OR}=0.89(0.80-0.99)\right.$; Figure $1 \mathrm{~A}$; Supplementary Table 2)

Earlier studies have shown that different histological subtypes of OC have different genetic and biological backgrounds and are associated with different aetiological pathways. Therefore, we stratified cases by histological subtype and repeated the analyses. In the combined sample set, there were 859 OC cases of the serous histological subtype, 274 endometrioid cases, 192 mucinous cases and 138 clear-cell cases. We found no additional evidence of genetic associations in the serous subtype, but we did find borderline evidence of association for one SNP each in the ERBB2 and PIK3CA genes with endometrioid OC and for three SNPS each in the BRAF and KRAS genes and one SNP in the NMI gene, all associated with mucinous OC. These data are summarised in Table 4.

We performed tests of association with common haplotypes for the five genes. There was no evidence of association with OC risk for haplotypes in KRAS and PIK3CA (Table 5). We found statistically significant haplotype effects for $B R A F, E R B B 2$ and NMI. Two haplotypes from ERBB2 were associated with an increased OC risk, h233 (OR $=1.17(1.02-1.34), P=0.022)$ and h411 (OR $=1.19(1.03-1.37), P=0.016)$, respectively. A haplotype in $B R A F, \mathrm{~h} 333423241$, was associated with a decrease in the risk of $\mathrm{OC}(\mathrm{OR}=0.81(0.68-0.95), P=0.012)$. Global tests of association were significant for BRAF $(P=0.005)$ and ERBB2 $(P=0.034)$. The association observed with the $N M I$ haplotype was fully explained by the single tSNP association.

\section{DISCUSSION}

Somatic alterations that activate proto-oncogenes and drive cells towards unregulated proliferation are a well-documented feature of all cancers. It has also become clear that different combinations of oncogenes contribute to the development of different tumour types. BRAF, ERBB2, KRAS and PIK3CA are all oncogenes shown to be involved in OC development, and NMI interacts with the oncogenes NMYC, MYC, MAX and FOS. NMI has also been shown to form a complex with MYC and BRCA1 and therefore may play a role in breast cancer and OC ( $\mathrm{Li}$ et al, 2002). In this study, we evaluated the association between 34 tSNPs in these genes and the risk of invasive epithelial OC using a case-control study design. To our knowledge, none of these genes has been investigated before for their association with invasive OC.

Table 2 tSNPs identified after genotyping in ovarian cancer cases and controls

\begin{tabular}{|c|c|c|c|c|c|c|c|c|}
\hline HapMap data & Gene & All SNPs & $\begin{array}{l}\text { Criteria } \\
\text { SNPs }\end{array}$ & $\begin{array}{l}\text { Tagging } \\
\text { SNPs }\end{array}$ & $\begin{array}{c}\text { SNPs } \\
\text { genotyped }\end{array}$ & $\begin{array}{c}\text { SNPs } \\
\text { captured } r^{2}>0.8\end{array}$ & $\begin{array}{c}\text { SNPs } \\
\text { captured } r^{2}>0.8(\%)\end{array}$ & $\begin{array}{c}\text { SNPs } \\
\text { captured } r^{2}>0.5\end{array}$ \\
\hline \multirow[t]{3}{*}{ Release $20^{a}$} & $B R A F$ & 158 & 75 & 9 & 8 & $72 / 75$ & 96 & $72 / 75$ \\
\hline & NMI & 45 & 25 & 6 & 6 & $25 / 25$ & 100 & $25 / 25$ \\
\hline & PIK $3 C A$ & 53 & 36 & II & 8 & $33 / 36$ & 92 & $34 / 36$ \\
\hline Total & & 331 & 188 & 40 & 34 & $176 / 188$ & 94 & $181 / 188$ \\
\hline \multirow{4}{*}{ Release $21 a^{b}$} & ERBB2 & 26 & 11 & 5 & 3 & $9 / 11$ & 82 & $9 / 11$ \\
\hline & KRAS & 69 & 55 & 11 & 9 & $50 / 55$ & 91 & $53 / 55$ \\
\hline & NMI & 52 & 32 & 6 & 6 & $32 / 32$ & 100 & $32 / 32$ \\
\hline & PIK3CA & 60 & 39 & 11 & 8 & $36 / 39$ & 92 & $39 / 39$ \\
\hline Total & & 371 & 212 & 42 & 34 & $199 / 212$ & 94 & $205 / 212$ \\
\hline
\end{tabular}

$\mathrm{SNP}=$ single-nucleotide polymorphism. Criteria SNPs: minor allele frequency $\geqslant 0.05$; Hardy-Weinberg equilibrium $\geqslant 0.01$. The captured SNPs refer to the number and proportion of criteria SNPs covered by the HapMap release. ${ }^{a}$ The tagging SNPs genotyped were selected using HapMap Data Release $20 .{ }^{b}$ The genes were retagged using the new HapMap data release ( 2 la), and the proportion of SNPs that were captured by the SNPs genotyped was determined. 
Table 3 Genotype-specific risks (OR and $95 \% \mathrm{Cl}$ ) of pooled stage I data

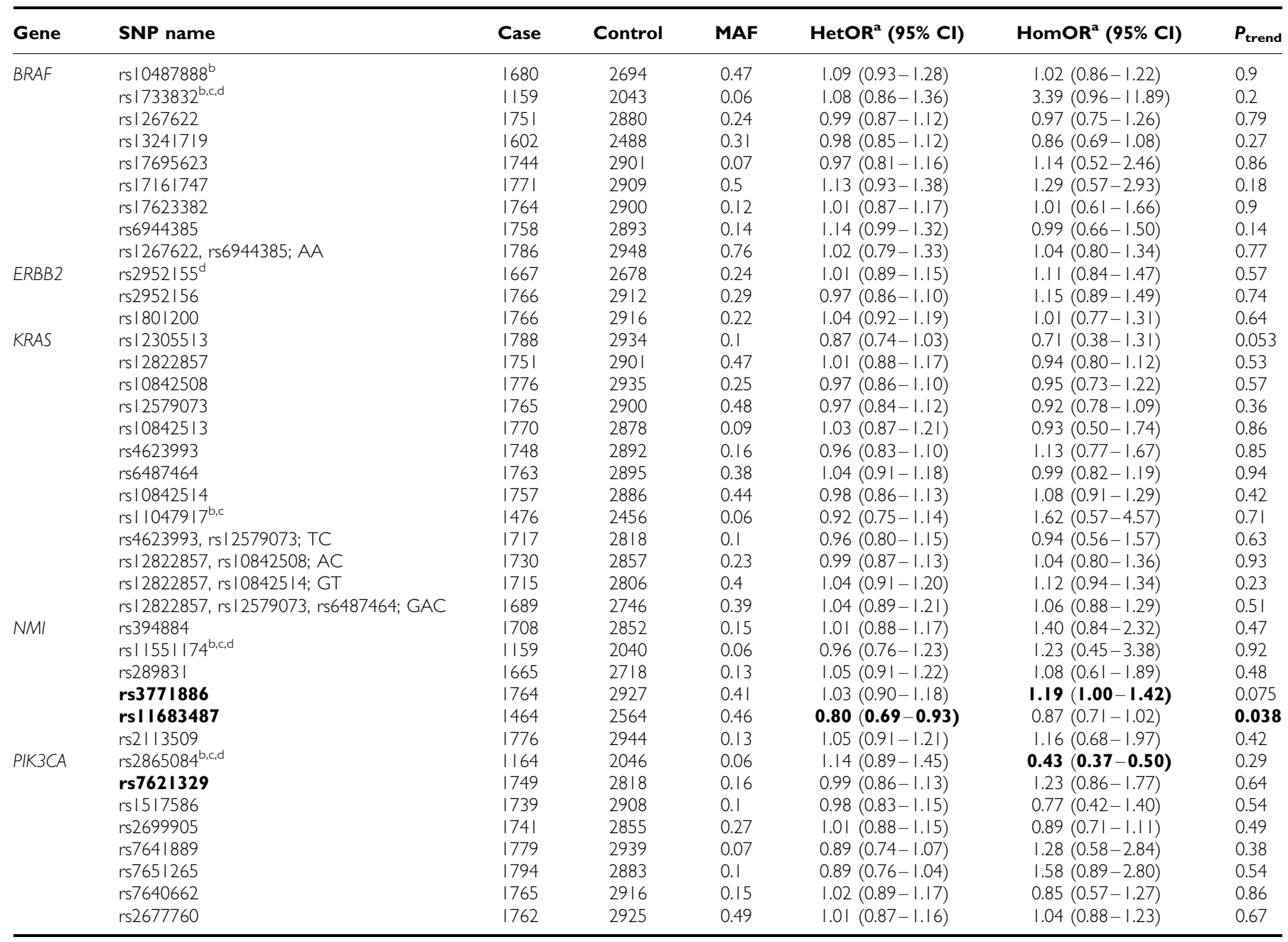

$\mathrm{Cl}=$ confidence interval; $\mathrm{MAF}=$ minor allele frequency; $\mathrm{OR}=$ odds ratio; SNP = single-nucleotide polymorphism. ${ }^{\mathrm{a} C o m p a r e d}$ with common homozygote. ${ }^{b} \mathrm{UKOPS}$ is excluded. CUSC is excluded. ${ }^{\mathrm{C}}$ GEOCS is excluded. Bold text indicates positive results, either by $P$-value or $\mathrm{Cl}$ ranges that do not cross 1.00 .

We found borderline evidence for a statistically significant association with disease risk for a tSNP, rs11683487, in intron 1 of the NMI gene. The common allele $(\mathrm{G})$ occurs in the Caucasian population with a frequency of approximately $58 \%$ and we observed that the rare allele $(\mathrm{T})$ was associated with a decreased risk of OC. The association for rs 11683487 may be a false positive. Where the prior probability of association is low, very stringent significance levels are required to ensure that a detected association is true positive. Genome-wide significance is generally considered to be $P<10^{-7}$ (Thomas et al, 2005). False-positive associations due to population stratification is also possible, but this seems an unlikely explanation for data from multiple studies from different populations in which the analyses were restricted to white subjects.

If the association we identified in NMI is real, then this could be either due to a direct causal effect of the tSNP or because the SNP is in linkage disequilibrium with the true causal variant, possibly in a different gene. $N M I$ enhances the transcription of several other genes altered in OCs $(M Y C ; N-M Y C)$ when it is induced by interleukin-2 and interferon- $\gamma$. The role of MYC amplification in ovarian and other cancers is well established. A detailed mapping of SNPs at a locus on chromosome 8q, near MYC, has recently provided substantial evidence that this locus is associated with susceptibility to breast, prostate and ovarian cancer (Ghoussaini et al, 2008). A further link comes from the finding that NMI forms a complex with MYC and BRCA1 (Li et al, 2002).

The NMI SNP rs11683487 tags eight other SNPs with $r^{2}>0.8$, one of which is a non-synonymous coding SNP (rs1048135) tagged with an $r^{2}=1$, and the rare $(G)$ allele codes for leucine instead of serine. We examined whether there is any evidence supporting the role of these SNPs in abrogating NMI function. The programme PMut (Ferrer-Costa et al, 2005) predicted that the rare allele (coding for leucine), with a score of $3 / 10$ had a 'pathological significance' and was classed as 'damaging' using the SIFT programme (Cheng et al, 2006). The bioinformatics tool, PupaSNP (http://pupasuite.bioinfo.cipf.es/) (Conde et al, 2006; Reumers et al, 2008), also suggested that this allele may disrupt the binding of exonic splicing enhancers. In addition, PupaSNP indicated that rs11683487 and rs11730 may have transcription and translation regulatory functions, and that rs11730 may affect exon splicing.

We found no evidence of association with disease risk for polymorphisms in $B R A F, E R B B 2, K R A S$ and PIK3CA at $P \leqslant 0.05$, when OC was considered as a single disease phenotype. The combined sample size from five studies provides $98 \%$ power at the $5 \%$ significance level to detect a co-dominant allele with a frequency of 0.3 that confers a relative risk of 1.2 , and $95 \%$ power 
to detect a dominant allele with a frequency of 0.1 that confers a relative risk of 1.3. It is therefore unlikely that the common tagged variants in these genes contribute significantly to OC risk. However, we cannot rule out the possibility that associations exist

\section{A}

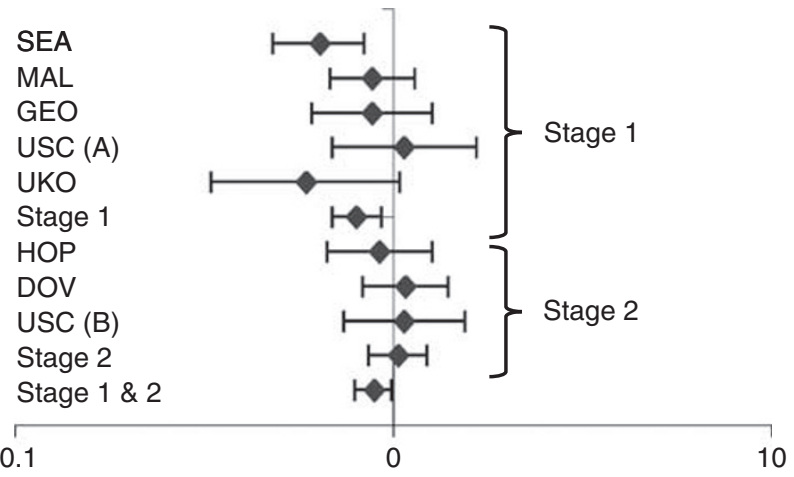

Heterozygous odds ratio

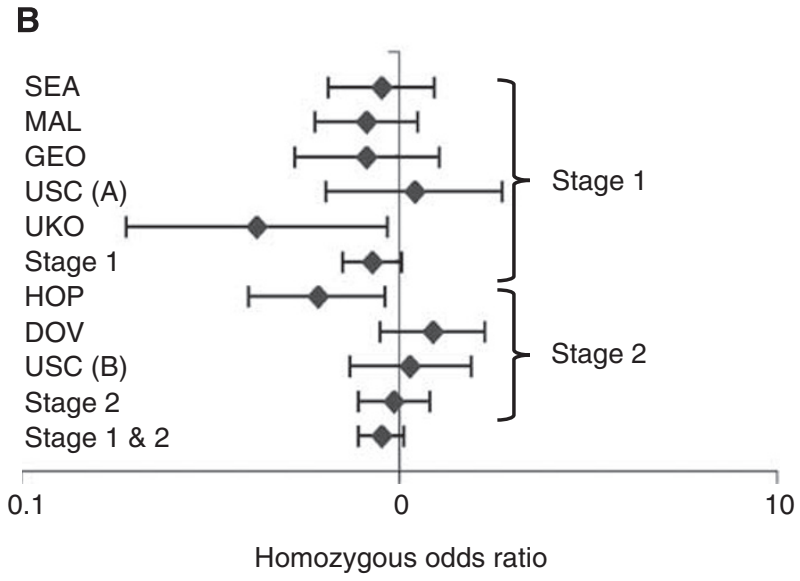

Figure I Forest plots of tSNP rs I 683487 in the NMI gene in ovarian cancer case-control populations. SEA - SEARCH, UK; MAL - MALOVA, Denmark; GEO - GEOCS, USA; USC - University of Southern California, USA; DOV - DOVE, USA; HOP - HOPE, USA; UKO - UKOPS, UK. (A) Heterozygous and (B) homozygous odds ratios for all invasive ovarian cancer cases. All cases combined: nominal model $-\mathrm{HetOR}=0.89(95 \% \mathrm{Cl}$ 0.79-0.99), HomOR 0.9 (0.78-1.03), $P_{\text {trend: }} 0.0831$; dominant model $\mathrm{OR}=0.87(0.8-0.99), P_{\text {dominant }}: 0.0317$. for the known poorly tagged variants. With the most recent HapMap data (release 21a), of the 212 common variants, 199 were tagged with $r^{2}>0.8$ and 205 with $r^{2}>0.5$. Furthermore, even though tSNPs based on HapMap data are likely to tag most of the common SNPs, there is a possibility that other unknown common variants were poorly tagged, or that less common variants in these genes that influence disease susceptibility exist.

We must also consider the possibility that common variants within these genes confer susceptibility to specific subtypes of OC. There is evidence in the literature that the genetic changes associated with OC development differ for different histological subtypes (reviewed in Elmasry and Gayther, 2005). For example, somatic activating KRAS mutations are found to some extent in most OC subtypes, but are much more common in mucinous ovarian tumours. Also, germline BRCA1 and BRCA2 mutations tend to predispose to serous OCs (Lakhani et al, 2004). We found some evidence of association with disease risk for different histological subtypes, for SNPs in all five of the oncogenes studied, and it is perhaps interesting that SNPs in the KRAS gene and its downstream effector $B R A F$ were associated with mucinous OC. However, the sample sizes after subtype stratification meant that these studies had insufficient power to detect associations at stringent levels of statistical significance, and so the data must be treated with caution. Much larger sample sizes, gathered through the ovarian cancer association consortium (OCAC), will be needed to establish if any of these associations are real.

Haplotype analysis identified significant associations in $B R A F$, $E R B B 2$ and NMI. The association between the NMI haplotype and risk of OC is explained by the single SNP rs11683487. The global test of haplotype effect was statistically significant for $B R A F$ and $E R B B 2$. Interestingly, the two haplotypes in ERBB2, which are significantly associated with increased risk of OC, contain the opposite allele at each SNP loci. Using HapMap data we evaluated whether these two putative risk haplotypes in ERBB2 shared an untagged common variant, but this was not the case. It is possible that there is an as-yet-unidentified variant that tags both haplotypes. There may be an allele that is found only in the protective haplotype of $B R A F$, which was not captured with our genotyping.

This study is one of the several in the published literature to use the multi-centre OCAC to follow-up on putative susceptibility alleles for OC (e.g., Gayther et al, 2007; Pearce et al, 2008; Ramus et al, 2008). These studies highlight the importance of consortia for validating suggested genetic associations from case-control studies and for identifying novel susceptibility loci for the disease. In addition to dramatically increasing the power of association studies, another role of consortia like the OCAC, has been to implement stringent data quality and genotyping guidelines, which are likely to minimise reports of false-positive associations.

Table 4 Genetic associations identified in the BRAF, KRAS, ERBB2, NMI and PIK3CA after histological subtype stratification

\begin{tabular}{|c|c|c|c|c|c|c|}
\hline Gene & SNP & Controls & Cases & HetOR & HomOR & $P_{\text {trend }}$ \\
\hline \multicolumn{7}{|c|}{ Endometrioid subtype } \\
\hline ERBB2 & rs 1801200 & 2916 & 263 & $1.16(0.88-1.52)$ & $1.71(1.05-2.76)$ & 0.0389 \\
\hline \multicolumn{7}{|c|}{ Mucinous subtype } \\
\hline \multirow[t]{2}{*}{ BRAF } & rs 10487888 & 2694 & 180 & $1.32(0.86-2.03)$ & $1.61(1.03-2.53)$ & 0.0357 \\
\hline & rs 1267622 & 2880 & 187 & $0.67(0.48-0.94)$ & $0.71(0.35-1.43)$ & 0.0278 \\
\hline \multirow{2}{*}{ KRAS } & rs6487464 & 2895 & 192 & $0.61(0.44-0.85)$ & $0.76(0.50-1.18)$ & 0.0379 \\
\hline & rs $108425 \mid 4$ & 2885 & 188 & $1.13(0.78-1.64)$ & $2.02(1.35-3.01)$ & 0.0006 \\
\hline NMI & rs|l 683487 & 2565 & 154 & $0.67(0.47-0.96)$ & $0.62(0.39-0.99)$ & 0.0269 \\
\hline
\end{tabular}

$\mathrm{SNP}=$ single-nucleotide polymorphism. 
Table 5 Haplotype analysis results for BRAF, ERBB2, KRAS, NMI and PIK3CA

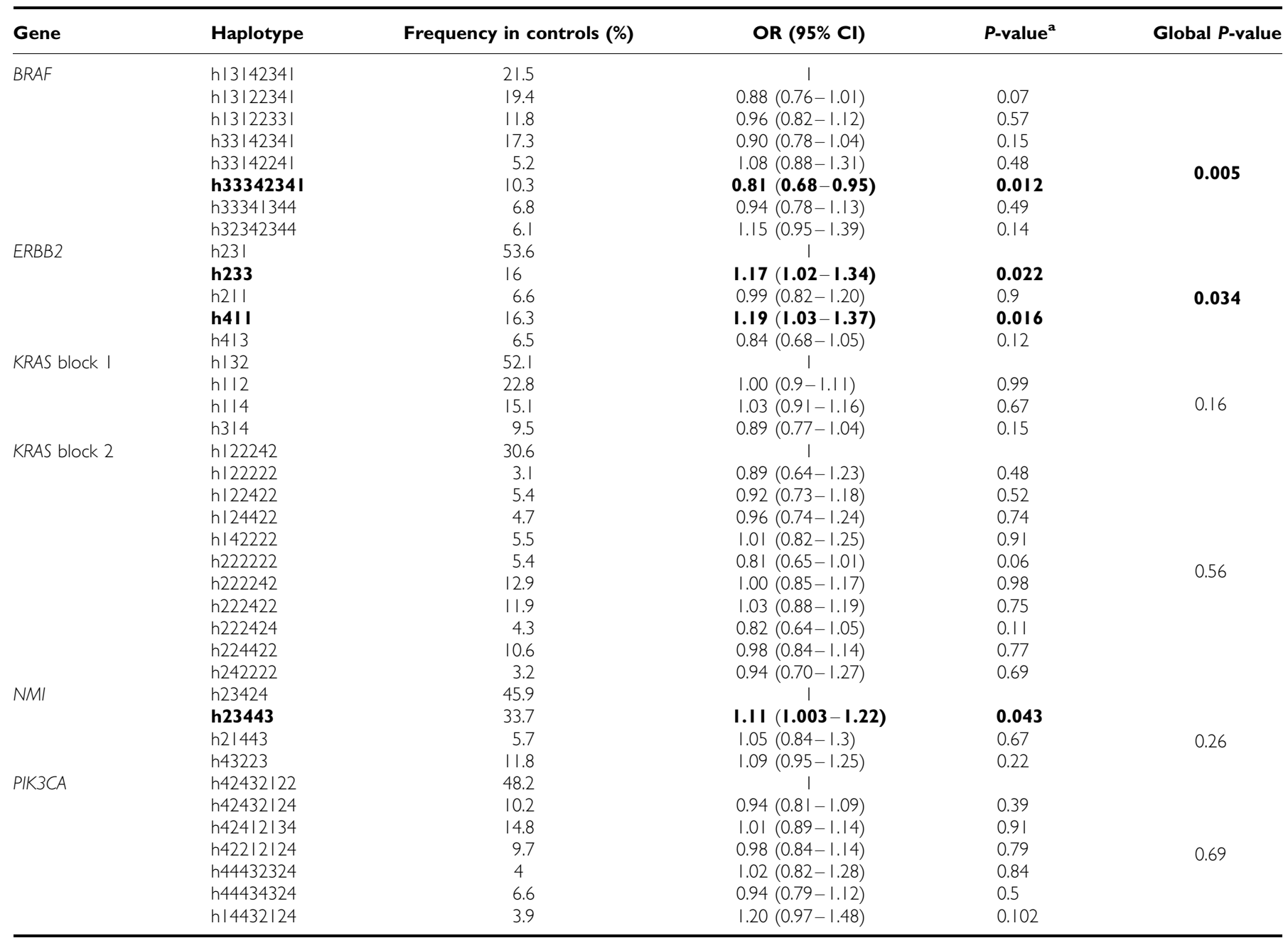

$\mathrm{Cl}=$ confidence interval; $\mathrm{MAF}=$ minor allele frequency; $\mathrm{OR}=$ odds ratio. In the haplotypes, the numbers correspond to nucleotides: $\mathrm{I}=\mathrm{A}, 2=\mathrm{C}, 3=\mathrm{G}, 4=\mathrm{T}$. $\mathrm{SNP}$ order in

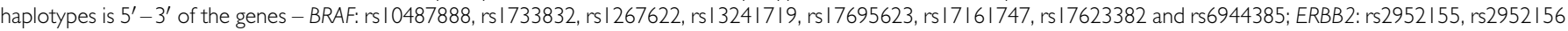
and rs I 80 I 200; KRAS (block I): rs I 23055 I 3, rs I 2822857 and rs I 0842508; KRAS (block 2): rs I 2579073, rs I 08425 I 3, rs4623993, rs6487464, rs I 08425 I 4 and rs I I 0479 I7; NMI: rs394884, rsII55II74, rs28983I, rs377I886 and rsII683487; PIK3CA: rs2865084, rs762I329, rsI5I7586, rs2699905, rs764I889, rs765I265, rs7640662 and rs2677760. ${ }^{a}$ Compared with common haplotype. Bold text indicates positive results, either by $P$-value or $\mathrm{Cl}$ ranges that do not cross 1.00 .

In conclusion, we genotyped 34 tSNPs that tag the common variants in BRAF, ERBB2, KRAS, NMI and PIK3CA in OC cases and controls. We found borderline evidence of a statistically significant association with invasive OC, for a SNP in NMI and haplotypes in $B R A F$ and $E R B B 2$. Further studies will be needed to confirm if this genetic risk association is real or not.

\section{ACKNOWLEDGEMENTS}

This study was undertaken at UCLH/UCL, which received a proportion of funding from the Department of Health's NIHR Biomedical Research Centres funding scheme. LQ is funded by the MRC. SJR is funded by the Mermaid component of the Eve Appeal, HS is funded by a grant from WellBeing of Women, DFE is a Principal Research Fellow of Cancer Research UK and PDPP is a Senior Clinical Research Fellow of Cancer Research UK. BAJP is a Gibb Fellow. Genotyping was funded by a Cancer Research UK project grant (no. C8804/A7058). The UKOPS study is funded by the OAK Foundation. Additional support was provided by The
Roswell Park Alliance and the National Cancer Institute (CA71766 and Core Grant CA16056) (GEOCS study); NIH Grant RO1 CA87538 (the DOVE study); NCI grants K07-CA80668 and R01CA095023, and Department of Defence Grant DAMD17-02-10669 (The HOPE project); and the California Cancer Research Program grants 00-01389V-20170 and 2110200, US Public Health Service grants CA14089, CA17054, CA61132, CA63464, N01-PC67010 and R03-CA113148, and California Department of Health Services sub-contract 050 -E8709 as part of its statewide cancer reporting programme (University of Southern California). We thank Joan MacIntosh, Hannah Munday, Barbara Perkins, Clare Jordan, Kristy Driver, Mitul Shah, the local general practices and nurses and the East Anglian Cancer Registry for recruitment of the Search cases: the EPIC-Norfolk investigators for recruitment of the Search controls, and Craig Luccarini and Don Conroy for expert technical assistance. We thank all members of the research team, including research nurses, research scientists, data entry personnel and consultant gynaecological oncologists, for their help in establishing the UKOPS case-control collection and Andy Ryan and Jeremy Ford for data and sample management. We also thank Debby Bass, Shari Hutchison, Carlynn Jackson, Jessica Kopsic and 
Mary Hartley for the HOPE project. Finally, we would like to express our profound thanks to all of the study participants who contributed to this research.

\section{REFERENCES}

Antoniou AC, Easton DF (2006) Risk prediction models for familial breast cancer. Future Oncol 2: 257-274

Bao J, Zervos AS (1996) Isolation and characterization of $\mathrm{Nmi}$, a novel partner of Myc proteins. Oncogene 12: $2171-2176$

Barrett JC, Fry B, Maller J, Daly MJ (2005) Haploview: analysis and visualization of LD and haplotype maps. Bioinformatics 21: 263-265

Cantley LC (2002) The phosphoinositide 3-kinase pathway. Science 296: $1655-1657$

Cheng J, Randall A, Baldi P (2006) Prediction of protein stability changes for single-site mutations using support vector machines. Proteins 62: $1125-1132$

Conde L, Vaquerizas JM, Dopazo H, Arbiza L, Reumers J, Rousseau F, Schymkowitz J, Dopazo J (2006) PupaSuite: finding functional single nucleotide polymorphisms for large-scale genotyping purposes. Nucleic Acids Res 34: W621 - W625

Cuatrecasas M, Erill N, Musulen E, Costa I, Matias-Guiu X, Prat J (1998) K-ras mutations in nonmucinous ovarian epithelial tumors: a molecular analysis and clinicopathologic study of 144 patients. Cancer 82: $1088-1095$

Cuatrecasas M, Villanueva A, Matias-Guiu X, Prat J (1997) K-ras mutations in mucinous ovarian tumors: a clinicopathologic and molecular study of 95 cases. Cancer 79: $1581-1586$

de Bakker PI, Yelensky R, Pe'er I, Gabriel SB, Daly MJ, Altshuler D (2005) Efficiency and power in genetic association studies. Nat Genet 37: $1217-1223$

Dicioccio RA, Song H, Waterfall C, Kimura MT, Nagase H, McGuire V, Hogdall E, Shah MN, Luben RN, Easton DF, Jacobs IJ, Ponder BA, Whittemore AS, Gayther SA, Pharoah PD, Kruger-Kjaer S (2004) STK15 polymorphisms and association with risk of invasive ovarian cancer. Cancer Epidemiol Biomarkers Prev 13: $1589-1594$

Elmasry K, Gayther SA (2005) Somatic genetic mutations and clinical outcome in gynaecological cancers. Gynaecological Forum 10: 5-11

Ferrer-Costa C, Gelpi JL, Zamakola L, Parraga I, de la Cruz X, Orozco M (2005) PMUT: a web-based tool for the annotation of pathological mutations on proteins. Bioinformatics 21: $3176-3178$

Forbes S, Clements J, Dawson E, Bamford S, Webb T, Dogan A, Flanagan A, Teague J, Wooster R, Futreal PA, Stratton MR (2006) Cosmic 2005. Br J Cancer 94: $318-322$

Ford D, Easton DF, Stratton M, Narod S, Goldgar D, Devilee P, Bishop DT, Weber B, Lenoir G, Chang-Claude J, Sobol H, Teare MD, Struewing J, Arason A, Scherneck S, Peto J, Rebbeck TR, Tonin P, Neuhausen S, Barkardottir R, Eyfjord J, Lynch H, Ponder BAJ, Gayther SA, Birch JM, Lindblom A, Stoppa-Lyonnet A, Bignon Y, Borg A, Hamann U, Haites N, Scott RJ, Maugard CM, Vasen H, Seitz S, Cannon-Albright LA, Schofield A, Zelada-Hedman M, and the Breast Cancer Linkage Consortium (1998) Genetic heterogeneity and penetrance analysis of the BRCA1 and BRCA2 genes in breast cancer families. The Breast Cancer Linkage Consortium. Am J Hum Genet 62: 676-689

Fruman DA, Meyers RE, Cantley LC (1998) Phosphoinositide kinases. Annu Rev Biochem 67: $481-507$

Gabriel SB, Schaffner SF, Nguyen H, Moore JM, Roy J, Blumenstiel B, Higgins J, DeFelice M, Lochner A, Faggart M, Liu-Cordero SN, Rotimi C, Adeyemo A, Cooper R, Ward R, Lander ES, Daly MJ, Altshuler D (2002) The structure of haplotype blocks in the human genome. Science 296: $2225-2229$

Gayther SA, Russell P, Harrington P, Antoniou AC, Easton DF, Ponder BA (1999) The contribution of germline BRCA1 and BRCA2 mutations to familial ovarian cancer: no evidence for other ovarian cancer-susceptibility genes. Am J Hum Genet 65: 1021-1029

Gayther SA, Song H, Ramus SJ, Kjaer SK, Whittemore AS, Quaye L, Tyrer J, Shadforth D, Hogdall E, Hogdall C, Blaeker J, DiCioccio R, McGuire V, Webb PM, Beesley J, Green AC, Whiteman DC, Goodman MT, Lurie G, Carney ME, Modugno F, Ness RB, Edwards RP, Moysich KB, Goode EL, Couch FJ, Cunningham JM, Sellers TA, Wu AH, Pike MC, Iversen ES, Marks JR, Garcia-Closas M, Brinton L, Lissowska J, Peplonska B, Easton DF, Jacobs I, Ponder BA, Schildkraut J, Pearce CL, Chenevix-Trench G,
Supplementary Information accompanies the paper on British Journal of Cancer website (http://www.nature.com/bjc)

Berchuck A, Pharoah PD (2007) Tagging single nucleotide polymorphisms in cell cycle control genes and susceptibility to invasive epithelial ovarian cancer. Cancer Res 67: $3027-3035$

Gemignani ML, Schlaerth AC, Bogomolniy F, Barakat RR, Lin O, Soslow R, Venkatraman E, Boyd J (2003) Role of KRAS and BRAF gene mutations in mucinous ovarian carcinoma. Gynecol Oncol 90: 378-381

Ghoussaini M, Song H, Koessler T, Al Olama AA, Kote-Jarai Z, Driver KE, Pooley KA, Ramus SJ, Kjaer SK, Hogdall E, DiCioccio RA, Whittemore AS, Gayther SA, Giles GG, Guy M, Edwards SM, Morrison J, Donovan JL, Hamdy FC, Dearnaley DP, Ardern-Jones AT, Hall AL, O'Brien LT, Gehr-Swain BN, Wilkinson RA, Brown PM, Hopper JL, Neal DE, Pharoah PD, Ponder BA, Eeles RA, Easton DF, Dunning AM (2008) Multiple loci with different cancer specificities within the $8 \mathrm{q} 24$ gene desert. J Natl Cancer Inst 100: $962-966$

Hellstrom I, Goodman G, Pullman J, Yang Y, Hellstrom KE (2001) Overexpression of HER-2 in ovarian carcinomas. Cancer Res 61: $2420-2423$

Hogdall EV, Hogdall CK, Blaakaer J, Christensen L, Bock JE, Vuust J, Glud E, Kjaer SK (2003a) K-ras alterations in Danish ovarian tumour patients. From the Danish 'Malova' Ovarian Cancer study. Gynecol Oncol 89: $31-36$

Hogdall EV, Christensen L, Kjaer SK, Blaakaer J, Bock JE, Glud E, Norgaard-Pedersen B, Hogdall CK (2003b) Distribution of HER-2 overexpression in ovarian carcinoma tissue and its prognostic value in patients with ovarian carcinoma: from the Danish MALOVA Ovarian Cancer Study. Cancer 98: 66-73

Lakhani SR, Manek S, Penault-Llorca F, Flanagan A, Arnout L, Merrett S, McGuffog L, Steele D, Devilee P, Klijn JG, Meijers-Heijboer H, Radice P, Pilotti S, Nevanlinna H, Butzow R, Sobol H, Jacquemier J, Lyonet DS, Neuhausen SL, Weber B, Wagner T, Winqvist R, Bignon YJ, Monti F, Schmitt F, Lenoir G, Seitz S, Hamman U, Pharoah P, Lane G, Ponder B, Bishop DT, Easton DF (2004) Pathology of ovarian cancers in BRCA1 and BRCA2 carriers. Clin Cancer Res 10: 2473-2481

Li H, Lee TH, Avraham H (2002) A novel tricomplex of BRCA1, Nmi, and c-Myc inhibits c-Myc-induced human telomerase reverse transcriptase gene (hTERT) promoter activity in breast cancer. J Biol Chem 277: 20965-20973

Lichtenstein P, Holm NV, Verkasalo PK, Iliadou A, Kaprio J, Koskenvuo M, Pukkala E, Skytthe A, Hemminki K (2000) Environmental and heritable factors in the causation of cancer - analyses of cohorts of twins from Sweden, Denmark, and Finland. $N$ Engl J Med 343: 78-85

Muller CI, Miller CW, Hofmann WK, Gross ME, Walsh CS, Kawamata N, Luong QT, Koeffler HP (2007) Rare mutations of the PIK3CA gene in malignancies of the hematopoietic system as well as endometrium, ovary, prostate and osteosarcomas, and discovery of a PIK3CA pseudogene. Leuk Res 31: $27-32$

Parkin DM, Bray F, Ferlay J, Pisani P (2005) Global cancer statistics, 2002. CA Cancer J Clin 55: 74-108

Pearce CL, Hirschhorn JN, Wu AH, Burtt NP, Stram DO, Young S, Kolonel LN, Henderson BE, Altshuler D, Pike MC (2005) Clarifying the PROGINS allele association in ovarian and breast cancer risk: a haplotype-based analysis. J Natl Cancer Inst 97: 51 - 59

Pearce CL, Wu AH, Gayther SA, Bale AE, Australian Cancer Study (Ovarian Cancer) and Australian Cancer Study Group, Beck PA, Beesley J, Chanock S, Cramer DW, DiCioccio R, Edwards R, Fredericksen ZS, Garcia-Closas M, Goode EL, Green AC, Hartmann LC, Hogdall E, Kjaer SK, Lissowska J, McGuire V, Modugno F, Moysich K, Ness RB, Ramus SJ, Risch HA, Sellers TA, Song H, Stram DO, Terry KL, Webb PM, Whiteman DC, Whittemore AS, Zheng W, Pharoah PD, Chenevix-Trench G, Pike MC, Schildkraut J, Berchuck A, Ovarian Cancer Association Consortium (2008) Progesterone receptor variation and risk of ovarian cancer is limited to the invasive endometrioid subtype: results from the Ovarian Cancer Association Consortium pooled analysis. Br J Cancer 98: $282-288$

Pharoah PD, Antoniou A, Bobrow M, Zimmern RL, Easton DF, Ponder BA (2002) Polygenic susceptibility to breast cancer and implications for prevention. Nat Genet 31: $33-36$ 
Ramus SJ, Harrington PA, Pye C, Peock S, Cook MR, Cox MJ, Jacobs IJ, DiCioccio RA, Whittemore AS, Piver MS, EMBRACE, Easton DF, Ponder BA, Pharoah PD, Gayther SA (2007) Screening for the BRCA1ins6kbEx13 mutation: potential for misdiagnosis. Mutation in brief \#964. Online. Hum Mutat 28: 525-526

Ramus SJ, Vierkant RA, Johnatty SE, Pike MC, Van Den Berg DJ, Wu AH, Pearce CL, Menon U, Gentry-Maharaj A, Gayther SA, Dicioccio RA, McGuire V, Whittemore AS, Song H, Easton DF, Pharoah PD, Garcia-Closas M, Chanock S, Lissowska J, Brinton L, Terry KL, Cramer DW, Tworoger SS, Hankinson SE, Berchuck A, Moorman PG, Schildkraut JM, Cunningham JM, Liebow M, Kjaer SK, Hogdall E, Hogdall C, Blaakaer J, Ness RB, Moysich KB, Edwards RP, Carney ME, Lurie G, Goodman MT, Wang-Gohrke S, Kropp S, Chang-Claude J, Webb PM, Chen X, Beesley J, Chenevix-Trench G, Goode EL (2008) Consortium analysis of 7 candidate SNPs for ovarian cancer. Int J Cancer 123: $380-388$

Reumers J, Conde L, Medina I, Maurer-Stroh S, Van Durme J, Dopazo J, Rousseau F, Schymkowitz J (2008) Joint annotation of coding and noncoding single nucleotide polymorphisms and mutations in the SNPeffect and PupaSuite databases. Nucleic Acids Res 36: D825-D829

Rhim JS (1988) Viruses, oncogenes, and cancer. Cancer Detect Prev 11: 139- 149

Rossing MA, Cushing-Haugen KL, Wicklund KG, Doherty JA, Weiss NS (2007) Menopausal hormone therapy and risk of epithelial ovarian cancer. Cancer Epidemiol Biomarkers Prev 16: 2548-2556

Russell SE, McCluggage WG (2004) A multistep model for ovarian tumorigenesis: the value of mutation analysis in the KRAS and BRAF genes. J Pathol 203: 617-619

Shayesteh L, Lu Y, Kuo WL, Baldocchi R, Godfrey T, Collins C, Pinkel D, Powell B, Mills GB, Gray JW (1999) PIK3CA is implicated as an oncogene in ovarian cancer. Nat Genet 21: $99-102$

Sieben NL, Macropoulos P, Roemen GM, Kolkman-Uljee SM, Jan Fleuren G, Houmadi R, Diss T, Warren B, Al Adnani M, De Goeij AP, Krausz T, Flanagan AM (2004) In ovarian neoplasms, BRAF, but not KRAS, mutations are restricted to low-grade serous tumours. J Pathol 202: 336-340

Song H, Ramus SJ, Kjaer SK, Hogdall E, Dicioccio RA, Whittemore AS, McGuire V, Hogdall C, Jacobs IJ, Easton DF, Ponder BA, Dunning AM,
Gayther SA, P DPP (2007) Tagging single nucleotide polymorphisms in the BRIP1 gene and susceptibility to breast and ovarian cancer. PLoS ONE 2: e268

Song H, Ramus SJ, Shadforth D, Quaye L, Kjaer SK, Dicioccio RA, Dunning AM, Hogdall E, Hogdall C, Whittemore AS, McGuire V, Lesueur F, Easton DF, Jacobs IJ, Ponder BA, Gayther SA, Pharoah PD (2006) Common variants in RB1 gene and risk of invasive ovarian cancer. Cancer Res 66: 10220 - 10226

Stram DO, Haiman CA, Hirschhorn JN, Altshuler D, Kolonel LN, Henderson BE, Pike MC (2003) Choosing haplotype-tagging SNPS based on unphased genotype data using a preliminary sample of unrelated subjects with an example from the Multiethnic Cohort Study. Hum Hered 55: $27-36$

Stratton JF, Gayther SA, Russell P, Dearden J, Gore M, Blake P, Easton D, Ponder BA (1997) Contribution of BRCA1 mutations to ovarian cancer. $N$ Engl J Med 336: $1125-1130$

Thomas DC, Haile RW, Duggan D (2005) Recent developments in genomewide association scans: a workshop summary and review. Am J Hum Genet 77: 337 - 345

Volinia S, Hiles I, Ormondroyd E, Nizetic D, Antonacci R, Rocchi M, Waterfield MD (1994) Molecular cloning, cDNA sequence, and chromosomal localization of the human phosphatidylinositol 3-kinase p110 alpha (PIK3CA) gene. Genomics 24: $472-477$

Wu Y, Soslow RA, Marshall DS, Leitao M, Chen B (2004) Her-2/neu expression and amplification in early stage ovarian surface epithelial neoplasms. Gynecol Oncol 95: 570-575

Zaykin DV, Westfall PH, Young SS, Karnoub MA, Wagner MJ, Ehm MG (2002) Testing association of statistically inferred haplotypes with discrete and continuous traits in samples of unrelated individuals. Hum Hered 53: 79-91

Zhao ZZ, Nyholt DR, Le L, Martin NG, James MR, Treloar SA, Montgomery GW (2006) KRAS variation and risk of endometriosis. Mol Hum Reprod 12: $671-676$

Zhu M, John S, Berg M, Leonard WJ (1999) Functional association of Nmi with Stat5 and Stat1 in IL-2- and IFNgamma-mediated signaling. Cell 96: 121 - 130 